\title{
COMMENTARIES
}

Agnieszka Jachec-Neale*

a.jachec-neale@exeter.ac.uk

Law School/Strategy and Security Institute

University of Exeter

Amory Building

Rennes Drive, Exeter

EX4 4RJ, United Kingdom

\section{UK's Cultural Property (Armed Conflicts) Act 2017 - Legislation 60 Years in Making}

\begin{abstract}
On 12 September 2017, the United Kingdom joined 128 other States in officially becoming party to the 1954 Hague Convention for the Protection of Cultural Property in the Event of Armed Conflict and its two Protocols. The UK first signed the Hague Convention in December 1954, but did not ratify it for 60 years. As political pressure mounted in recent years to recognize the necessity of safeguarding of cultural heritage both at home and abroad, the current government undertook to rectify the delay in bringing the UK's obligations up to international standards in this field. This paper examines both the process and its legislative outcome. It argues that this ratification came as a much-awaited and welcome step, in particular because it allows for domestic prosecutions of serious
\end{abstract}

\footnotetext{
* Dr. Agnieszka Jachec-Neale is an expert researcher and lecturer with practical insight into how international law is applied during armed conflict and in post-conflict environments. Her research focuses on investigating the protective regime for the various categories of objects, such as medical units/hospitals, civilian objects including schools, and other categories such as UN peacekeeping missions' facilities and critical infrastructure. As a part of that she is examining the impact of the destruction of cultural property and protective status of protected religious sites during armed conflict, such as mosques and churches. Agnieszka teaches in Exeter Law School, Strategy and Security Institute and at the Humanitarian Disaster and Relief Theory (MSc Extreme Medicine) in Medical School, all at the University of Exeter, UK. She is currently President of the International Humanitarian Law Committee of International Society for Military Law and the Laws of War.
}

The author wishes to express her thanks to Dr. Kubo Mačak and Prof. Rebecca Probert, both of University of Exeter, as well as the anonymous reviewers for their helpful comments and suggestions. 


\section{COMMENTARIES}

Agnieszka Jachec-Neale

breaches of the Second Protocol against non-nationals. By contrast, the ratification represented a missed opportunity to tackle some of the more challenging and topical issues related to the material and personal scope of application of the Hague Convention and its Protocols, as well as to the definition of cultural property.

Keywords: United Kingdom, Cultural Property Act, non-state organized armed groups, criminal responsibility, protection, 1954 Hague Convention, non-international armed conflicts, Syria

\section{Introduction}

On 12 September 2017, the United Kingdom joined 128 other States in officially becoming Party to the 1954 Hague Convention for the Protection of Cultural Property in the Event of Armed Conflict ("the Hague Convention") and its two Protocols. ${ }^{1}$ The UK had been the last member of the UN Security Council to ratify the Hague Convention, but became the second - after France - to ratify the treaty together with both its Protocols.

It had been a long time coming. The UK first signed the Hague Convention in December 1954, but did not ratify it for 60 years because, together with a number of other countries, it considered that the treaty did not provide an effective regime for the protection of cultural property. ${ }^{2}$

As political pressure grew to recognize the necessity of safeguarding of cultural heritage both at home and abroad, Theresa May's government undertook to rectify the delay in bringing the UK's obligations up to international standards in this field. ${ }^{3}$ Taking into account the passage of time and the changing realities of modern warfare, one would have expected the ratification of the treaty to have created an opportunity to examine in more depth the problems surrounding the applicability of the treaty in the context of modern conflicts. But was this undertaken, and what has been achieved in the process? This paper aims to examine the process

1 Convention for the Protection of Cultural Property in the Event of Armed Conflict, 14 May 1954, 249 UNTS 240, reprinted in: D. Schindler, J. Toman (eds.), The Laws of Armed Conflicts, 4th edn., Martinus Nijhoff, Leiden 2004, pp. 999-1025; Protocol for the Protection of Cultural Property in the Event of Armed Conflict, 14 May 1954, 249 UNTS 358 ("First Protocol"), reprinted in: ibidem, pp. 1027-1033; Second Protocol to the Hague Convention for the Protection of Cultural Property in the Event of Armed Conflict, 26 March 1999, 2253 UNTS 212 ("Second Protocol”), reprinted in: ibidem, pp. 1037-1051.

2 Department for Culture, Media and Sport, Draft Cultural Property (Armed Conflicts) Bill, January 2008, Cm 7798 ("Draft Bill 2008"), p. 84.

3 Department for Culture, Media and Sport, Ratification of 1954 Hague Convention for the Protection of Cultural Property in the Event of Armed Conflict and Accession to Its Two Protocols (of 1954 and 1999), Impact Assessment, 1 May 2016, pp. 1, 5. 
and its legislative outcome. It will first look into the legislative history of the UK's ratification process. It will then offer some comments about the Cultural Property (Armed Conflicts) Act 2017, focusing in particular on three areas subject to more intense Parliamentary debates - namely the material and personal applicability of the Act and the scope of the definition of cultural property as incorporated in the Act.

\section{Legislative History}

\section{Pre-2015 efforts to ratify the Hague Convention}

The delay in ratifying the Hague Convention was never the result of a lack of interest in, or respect for, the rules governing the protection of cultural property. The UK not only signed the Hague Convention in 1954, but also played an active part in drafting the Convention in the early 1950s. ${ }^{4}$ The UK did not accede at that time to its First Protocol. ${ }^{5}$ At the same time, a number of the UK's proposals were clearly not accepted in the final version of the Hague Convention, including those related to criminal responsibility. ${ }^{6}$ As a result, UK governments became adverse to ratification and, as stated in 1958 , felt that the provisions were "very complex" and required further examination. ${ }^{7}$ Subsequently, the UK explained its position in more detail. In 2014, the Department for Culture, Media and Sport said that the Hague Convention "did not provide an effective regime for the protection of cultural property", it "did not contain adequate criminal sanctions" and that it contained imprecise terms. ${ }^{8}$ The type of protection enshrined in the First Protocol, i.e. special protection aimed to prevent the export of cultural property from the occupied territories, was also deemed too political.9 Following a joint Dutch and UNESCO review in 1991 of the working of the Hague Convention and the Protocol, the Second Protocol was adopted in 1999. The UK had also been involved in negotiating this latter Protocol. ${ }^{10}$ The adoption of the Second Protocol dispelled all the concerns

\footnotetext{
4 UNESCO, Records of the Conference Convened by the United Nations Educational, Scientific, and Cultural Organization, Held at The Hague from 21 April to 14 May 1954, Staatsdrukkerij- en Uitgeverijbedrijf, The Hague 1961.
}

5 The UK signed the Hague Convention on 30 December 1954. The UNESCO Convention for the Protection of Cultural Property in the Event of Armed Conflict with Regulations for Execution of the Convention 1954 - Opened for Signature is available here: http://portal.unesco.org/en/ev.php-URL_ID=13637\&URL_ DO=DO_TOPIC\&URL_SECTION=201.htmI\#SIGNATURE [accessed: 14.01.2018].

6 UNESCO, Records..., p. 390, UNESCO Docs CBC/DR/87 (UK).

7 Protection of Cultural Property (Convention), HC Deb (19 November 1958) vol. 595 col. 1142.

8 House of Commons, Culture, Media and Sport Committee, Draft Cultural Property (Armed Conflicts) Bill, 15 July 2008, HC 693 ("CMSC Draft Bill"), pp. 6-7; Department for Culture, Media and Sport, Hague Convention 1954, 12 February 2014, http://old.culture.gov.uk/what_we_do/cultural_property/6630.aspx [accessed: 20.09.2017].

9 Department for Culture, Media and Sport, Hague Convention 1954.

10 Ibidem. 


\section{COMMENTARIES}

Agnieszka Jachec-Neale

that the UK authorities had previously had. ${ }^{11}$ Consequently, after the Second Protocol came into force in March 2004, the UK announced its readiness to ratify the Hague Convention and its two Protocols in May 2004, on the 50th anniversary of the adoption of the Hague Convention and its First Protocol. In the following year, the Department for Culture, Media and Sport undertook a consultation exercise on the implementation of the Hague Convention, the responses to which were published in October 2006.12

The 2005 Department for Culture, Media and Sport survey showed clearly that existing domestic laws were inadequate to meet the obligations of the Hague Convention, particularly in the area of criminal sanctions. ${ }^{13}$ For example, none of the existing criminal offences under Section 1(1) of the Geneva Conventions Act 1957, or Section 51 of the International Criminal Court Act 2001, were considered adequate. ${ }^{14}$ The definition of cultural property under the Hague Convention was broader than in any of these acts..$^{15}$ In addition, the British legislation did not address the offence of using cultural property under enhanced protection in support of military operations, as required by Article 15(1)(b) of the Second Protocol.

Furthermore, there was no specific protection given to the distinctive emblem of the Hague Convention, the Blue Shield emblem, despite the requirement of Article 16 of the Hague Convention. The Geneva Conventions Act 1957 only provided for the protection of the Red Cross and its related emblems. The Act enshrined the prohibition of any perfidious use of these emblems, ${ }^{16}$ in line with the requirements of Article 85(3) of Additional Protocol I to the 1949 Geneva Conventions. ${ }^{17}$ There were three problems with this Act vis-à-vis the Hague Convention. First, it was not clear whether this actually covered the specific cultural property emblem, or just the Red Cross, Red Crescent, and now Red Crystal emblems. Secondly, Article 85(3)(f) of Additional Protocol I considers "perfidious use" of a cultural emblem as a grave breach of this Protocol, however Article 17 of the Second Protocol sets out broader con-

\footnotetext{
11 Draft Bill 2008.
}

12 Department for Culture, Media and Sport, Consultation Paper on: The 1954 Hague Convention on the Protection of Cultural Property in the Event of Armed Conflict and its two Protocols of 1954 and 1999, September 2005, http://webarchive.nationalarchives.gov.uk/20100512164615/http://www.culture.gov.uk/images/ consultations/HagueConvention.pdf [accessed: 20.09.2017].

13 Department for Culture, Media and Sport, Government Response to the Culture, Media and Sport Committee Reports on the Draft Heritage Protection Bill and Draft Cultural Property (Armed Conflicts) Bill, October 2008, Cm 7472 (“Government Response 2008”), pp. 22-24.

14 Department for Culture, Media and Sport, Cultural Property (Armed Conflicts) Bill, Explanatory Notes, published together with Draft Bill, May 2016, para. 13.

15 Draft Bill 2008, p. 85.

16 Section 6 of Geneva Conventions Act 1957, Chapter 525 and 6 Eliz 2, 31 July 1957, with subsequent amendments.

17 Protocol Additional to the Geneva Conventions of 12 August 1949, and Relating to the Protection of Victims of International Armed Conflict (Protocol I), 8 June 1977, 1125 UNTS 3 ("Additional Protocol I"), reprinted in: D. Schindler, J. Toman (eds.), op. cit., pp. 711-773. 
ditions of situations in which such "use" is forbidden; uses which, in most cases, will not be perfidious. ${ }^{18}$ Thirdly, the Hague Convention also extended its reach to armed conflicts of a non-international character, which was outside the scope of the relevant provisions of the Geneva Conventions Act 1957. As such, this Act was deemed insufficient to fulfil the requirements of the Hague Convention regime. ${ }^{19}$

Specifically in relation to the 1954 First Protocol, the UK's existing legislation lacked a fully comprehensive set of measures designed to suppress any unlawful export of cultural property, taking into custody such property imported from occupied territory, or its return upon the close of hostilities. Whilst there have been some offences which could have been applied in relation to cases where there was allegedly an unlawful exportation of cultural property from an occupied territory - in accordance with the Dealing in Cultural Objects (Offences) Act 2003, Section 3(1)(a) of which criminalizes the import of "tainted" cultural property - the Act did not include any provisions enabling the seizure (retention in custody) or return of that cultural property. ${ }^{20}$ Equally, there were no effective measures to grant immunity from "seizure, placing in prize or capture" of any cultural property and any means of transport exclusively involved in the transfers of such property protected under Articles 12 and 13, particularly when on the UK's territory. ${ }^{21}$

The introduction of new legislation to address the shortcomings of the existing framework was preferable to the possible risk of the UK being in breach of its obligations under the Hague Convention. In January 2008, draft legislation was published as the Draft Cultural Property (Armed Conflicts) Bill. ${ }^{22}$ The draft Bill was, by and large, very well received among Parliamentarians. ${ }^{23}$ The Government's plan at that time was to introduce primary legislation, entitled The Cultural Heritage Bill, alongside the Bill on cultural property. This was, however, never tabled for consideration by subsequent Parliaments. ${ }^{24}$

The unquestionable need to ratify the Hague Convention had clearly matured by 2008 and was driven by two underlying considerations. First, the Government felt that it was necessary to formalize the responsibilities of members of the UK's armed forces operating in armed conflicts overseas..$^{25}$ Secondly, the pro-

18 See also Section 1(1) of Geneva Conventions Act 1957. Department for Culture, Media and Sport, Cultural Property (Armed Conflicts) Bill, Explanatory Notes, para. 15.

19 Ibidem.

20 "Tainted" cultural objects are defined as those which are unlawfully removed or excavated, after 30 December 2003, from a building or structure, monument of historical, architectural, or archaeological interest, whether in UK or abroad. Section 2(1-3) of Dealing in Cultural Objects (Offences) Act 2003, Chapter 27, 30 October 2003; Draft Bill 2008, p. 86.

21 Article 14 of the Hague Convention.

22 Draft Bill 2008.

23 CMSC Draft Bill, p. 3.

24 Government Response 2008, p. 3.

25 Draft Bill 2008, p. 89. 


\section{COMMENTARIES}

Agnieszka Jachec-Neale

tections offered by the Hague Convention were seen as ensuring the protection of the UK's cultural property in the event of an armed conflict involving a State which was High Contracting Party to this treaty. ${ }^{26}$ This constitutes recognition of the important incentive of reciprocal protection which is contained in the Hague Convention and its Protocols.

Most importantly, the 2008 draft Bill affirmed the UK's existing commitment to implementing the rules related to the protection of cultural property in armed conflicts. It recognized that the 1954 Hague Convention had been treated by British armed forces as being part of customary international law. ${ }^{27}$ In practice, the relevant rules were included in the Tri-Service Manual and, as such, became part of the training for British troops. ${ }^{28}$ This included the fundamental rules of ensuring respect for cultural property when undertaking military operations, and taking reasonable care to avoid attacking cultural property, even if it was being used for military purposes.

The UK's recent involvement in armed conflicts has certainly not raised major concerns about compliance with the norms dedicated to the protection of cultural property. Bearing all this in mind, the Culture, Media and Sport Committee concluded in 2008 that the future Act was unlikely to restrain military operations unduly. ${ }^{29}$ On the contrary, the Committee felt that it would "if enacted, strengthen the procedures used by the Ministry of Defence when training personnel in respect of cultural property and taking cultural sites into account when planning operations". 30

\section{Renewed push towards ratification (2015-2017)}

Despite its seemingly cross-party support and the occasional reiteration of the Government's commitment to ratify the Hague Convention, the effort to actually put this Bill through the Parliamentary process was not revived until mid-2015, when the Government announced it was committed to securing the relevant legislation at the "earliest opportunity". ${ }^{31}$

\footnotetext{
26 Ibidem, p. 84.

27 Ibidem, p. 89.

28 Ibidem. This was reiterated by the Government in 2016, when it stated that armed forces acted "as though bound by the Hague Convention" and that the Convention and its Protocols had already informed the armed forces in relation to the "law of armed conflict doctrine and training policy, particularly with regard to respect for cultural property, precautions in attack and recognition of the Blue Shield". Statement of Baroness Neville-Rolfe, Parliamentary Under-Secretary of State, Department for Business, Innovation and Skills and Department for Culture, Media and Sport, HL Deb 14 January 2016 vol. 768 cols. 501-502.

29 CMSC Draft Bill, p. 3.

30 Ibidem.

31 Statement by John Whittingdale, Secretary of State for Culture, Media and Sport, released on 21 June 2015, mentioned in: Council for British Archaeology, CBA Pushes for Definite Timescales for Protection
} 
At the start of the 2016-2017 Parliamentary session, the draft Bill was not included in the Queen's Speech, which normally contains a list of the legislation that the Government intends to introduce..$^{32}$ However, it was mentioned in the background notes attached to the Queen's Speech. ${ }^{33}$ Consequently, the Bill was introduced before the House of Lords on 19 May 2016. ${ }^{34}$ By September 2016, the "Cultural Property (Armed Conflicts) Bill [HL] 2016-17" had been through several rounds of discussions and was then passed to the House of Commons. ${ }^{35}$ Here, the proposed Bill [no. 66] underwent another three rounds of readings and debates, leading to it receiving Royal Assent on 23 February 2017. The Bill was considered and agreed upon with remarkable speed. This does not, however, mean that the discussions did not involve some important contemporary questions. The following section will address some of the key aspects of discussion of the specific elements of the Act that were raised during the debates in the Parliament.

\section{Key Debates}

A number of issues were raised during the debates, but two stand out and deserve a more detailed examination, both of which focus on the relationship between domestic regulation and international standards. First, the issue of the scope of the application of the Act, specifically focusing on the type of situations to which it is applicable, will be examined and juxtaposed with the applicability of the Hague Convention and its Protocols. This will be followed by a consideration of the scope of the definition of cultural property as adopted in the Act in the context of the current debate in international law.

\section{Scope of application of the Bill}

During the discussions in the House of Commons, a couple of Members of Parliament expressed concern that the final Act might not cover organizations such as Daesh or Boko Haram because "they are not covered by the protocols to the convention" ${ }^{36}$,

of Cultural Property, 21 June 2015, http://new.archaeologyuk.org/news/cba-pushes-for-definite-timescales-for-protection-of-cultural-property [accessed: 27.01.2018] and earlier signalized by Ed Vaizey, Minister of State for Culture and Digital Economy (HC Deb 4 June 2015 vol. 596 col. 739).

32 Cabinet Office, Queen's Speech 2016, 18 May 2016, https://www.gov.uk/government/speeches/ queens-speech-2016 [accessed: 15.01.2018].

33 Cabinet Office, Queen's Speech 2016: Background Briefing Notes, 18 May 2016, https://www.gov.uk/government/uploads/system/uploads/attachment_data/file/524040/Queen_s_Speech_2016_background_ notes_.pdf [accessed: 15.01.2018], pp. 53-54.

34 UK Parliament, Bill Stages - Cultural Property (Armed Conflicts) Act 2017, https://services.parliament.uk/ bills/2016-17/culturalpropertyarmedconflicts/stages.html [accessed: 28.09.2017].

35 Ibidem.

36 Statement of Tim Loughton, MP, Cultural Property (Armed Conflicts) Bill, HC Deb 31 October 2016 vol. 616 col. 734 . 


\section{COMMENTARIES}

Agnieszka Jachec-Neale

or that it would not apply in the context of Afghanistan because the "occupying forces" such as the Taliban were not "recognised states [sic]", ${ }^{37}$ and Afghanistan had not ratified the convention. In response, the Government representative suggested that the application of the Act would apply to situations in Syria to a certain extent because "the UK does not recognise Daesh as a state and because Syria has not ratified the second protocol". ${ }^{38}$ One may thus get the impression that it was assumed the Act would apply only to States, and only if the other State was also bound by the Second Protocol.

These various statements raise a number of different legal questions in relation to the scope of the application of the Act, which the parliamentarians managed to intertwine. One may ask at least three interrelated but distinct questions here, which may not yield the same answers. First, would the Act apply to situations of a non-international character, as do the 1954 Hague Convention and its Second Protocol? This may include the conflicts in Syria, Iraq, or Afghanistan, depending on the characterization of situations occurring between certain organized armed groups and other parties to conflicts on the territories of these States. ${ }^{39}$ A different, albeit related, question relates to whether the Hague Convention and the adopted Act would apply to non-State parties to conflicts. The answer to this question would clarify whether the Hague Convention and the ratifying Act could apply to armed groups such as Daesh or the Taliban. If the parliamentarians' underlying concern was over the recent rise in violations of the rules prohibiting damage and destruction to cultural property, then the more valid question would be whether the breaches of the Hague Convention - and thus also of the Act - can give rise to individual criminal responsibility among members of organized armed groups accused of committing such offences in the context of non-international armed conflicts. This section will address all three issues in turn.

\section{a) Do the Hague Convention and its Protocols apply to non-international armed con- flicts?}

Articles 18 and 19 of the Hague Convention prescribe the limits of the application of the Convention. Article 18 refers to situations of an international character, much in line with the wording of the common Article 2 to the four 1949 Geneva Conventions. ${ }^{40}$ The 1954 Hague Convention thus applies to all declared wars,

37 Statement of Kevin Brennan, MP, Cultural Property (Armed Conflicts) Bill, HC Deb 31 October 2016 vol. 616 col. 704.

38 Statement of Tracey Crouch, Parliamentary Under-Secretary of State for Culture, Media and Sport, Cultural Property (Armed Conflicts) Bill, HC Deb 31 October 2016 vol. 616 col. 738.

39 See for instance: F. Hampson, Afghanistan 2001 onwards, and M. Schmitt, Iraq 2003 Onwards, both in: E. Wilmshurst (ed.), International Law and Classification of Armed Conflicts, Oxford University Press, Oxford 2012; T.D. Gill, Classifying the Conflict in Syria, "International Law Studies" 2016, Vol. 92, pp. 353-380.

40 Article 2, as in Geneva Convention (I) for the Amelioration of the Condition of the Wounded and Sick in Armed Forces in the Field, 12 August 1949, 75 UNTS 31, reprinted in: D. Schindler, J. Toman (eds.), op. cit., pp. 459-484 and reproduced in the three remaining 1949 Geneva Conventions. See also International Com- 
armed conflicts arising between State Parties, and cases of total or partial occupation. ${ }^{41}$ It applies from the moment of the actual start of hostilities or, in cases of occupation, even in the absence of hostilities. ${ }^{42}$

Article 19 of the Hague Convention provides for application of the Convention to non-international armed conflicts occurring within the territory of a State which is Party to the Convention. This article was modelled on both the normative content and the language of Article 3, which is common to all four 1949 Geneva Conventions. ${ }^{43}$ The provision stipulates that all parties to a conflict of a non-international character are bound, at a minimum, by those provisions of the Hague Convention which relate to respect for cultural property. ${ }^{44}$ The extent to which their obligations to respect cultural property are triggered by the operation of this formulation remains debatable. Whilst most commentators would agree that this would cover Article 4 of the Hague Convention, ${ }^{45}$ some others would support a broader application of all provisions relevant to ensuring respect for cultural property. ${ }^{46}$

A further development came with the adoption of the 1999 Second Protocol to the 1954 Hague Convention. Article 3 of the Second Protocol set general parameters of ratione materiae application, and linked these to both Article 18 of the Hague Convention and the related Article 22(1) of the Protocol. Article 3 of the Second Protocol recognized that some provisions of the Protocol apply both in situations of peace and armed conflict, whether of an international or non-international character. Like Article 18 of the Hague Convention, Article 3(2) of the Protocol enabled the effective application of the Protocol between a State Party and a non-Party to the Protocol by enabling the latter to accept and comply with the provisions of the Second Protocol.

Article 22 of the Second Protocol contained a formula which was a bit different to Article 19 of the Hague Convention, and which enabled its substantively ex-

mittee of the Red Cross, Commentary on the First Geneva Convention: Convention (I) for the Amelioration of the Condition of the Wounded and Sick in Armed Forces in the Field, 2nd edn., Cambridge University Press, Cambridge 2016, https://ihl-databases.icrc.org/ihl/full/GCl-commentary [accessed: 14.01.2018].

41 Article 18(3) of the Hague Convention.

42 J. Toman, The Protection of Cultural Property in the Event of Armed Conflict: Commentary on the Convention for the Protection of Cultural Property in the Event of Armed Conflict and Its Protocol, Signed on 14 May 1954 in the Hague, and on Other Instruments of International Law Concerning Such Protection, Aldershot, Dartmouth 1996, pp. 196-197.

43 Idem, Cultural Property in War: Improvement in Protection: Commentary on the 1999 Second Protocol to the Hague Convention of 1954 for the Protection of Cultural Property in the Event of Armed Conflict, UNESCO, Paris 2009, pp. 392 and 396; UNESCO, Records..., as mentioned in J. Toman, The Protection..., pp. 207-209, 313.

44 Article 19(1) of the Hague Convention (emphasis added).

45 R. O'Keefe, The Protection of Cultural Property in Armed Conflict, Cambridge University Press, Cambridge 2006, p. 98; Article 4 of the Hague Convention prescribes conditions for the respect of cultural property by refraining from, among others, any use of the property for purposes that are likely to expose it to destruction or damage and from acts of hostility against such property including reprisals.

46 C. Forrest, International Law and the Protection of Cultural Heritage, Routledge, London 2010, p. 84. 


\section{COMMENTARIES}

Agnieszka Jachec-Neale

tended application. Article 22(1), unlike Article 19(1), did not restrict its application to certain provisions related to respect for cultural property. ${ }^{47}$ Instead it stipulated simply that the Protocol would apply in cases of non-international armed conflicts occurring "within the territory of one of the Parties". ${ }^{48}$ This meant that the Protocol's regime of enhanced protection would also be binding in situations of non-international armed conflicts. ${ }^{49}$

Through the concurrent ratification of the Hague Convention and both Protocols without any substantive changes, the Cultural Property (Armed Conflicts) Act 2017 will apply to international armed conflicts on the UK's own territory, as well as enemy territory if that State is also a Party to the Convention or if it accepts and applies the Convention. ${ }^{50}$ This will enable the UK to supplement the legal framework of the Hague Convention. It will also allow it to replace the special protection regime, regulated by the First Protocol, with the enhanced protection enshrined in the Second Protocol for property that has been awarded the status of both special and enhanced protection.

The Act will also apply to non-international armed conflicts occurring on the UK's territory and on foreign territory where the UK is engaged in a conflict of a non-international character and the territory belongs to a State which is Party to the Second Protocol. In the context of the UK's operations against Daesh, this means that the Hague Convention would apply, whilst the Second Protocol would not. This is because the Hague Convention has been ratified by both Syria and Iraq, but neither of these States are Parties to the Second Protocol. ${ }^{51}$ Thus, in this case, the UK would be bound to apply the provisions of the Hague Convention. It may, as a matter of policy, also apply those enshrined in the Second Protocol, but it is not obliged to do so. In the context of the conflict in Afghanistan, none of the relevant treaty provisions would be applicable due to the fact that Afghanistan is not a Party to the Hague Convention nor its Protocols. ${ }^{52}$ It is worth noting that, aside from the conventional obligations considered in the context of the Act,

\footnotetext{
47 Article 22 represents a blend of various formulas borrowed from common Article 3 of 1949 Geneva Conventions and the Protocol Additional to the Geneva Conventions of 12 August 1949, and Relating to the Protection of Victims of Non-International Armed Conflicts (Protocol II), 8 June 1977, 1125 UNTS 609 ("Additional Protocol II"), reprinted in: D. Schindler, J. Toman (eds.), op. cit., pp. 775-818.

48 Article 22(1) of the Second Protocol. Both Toman and O'Keefe advocate reading this provision in the context of both the common Article 3 to the 1949 Geneva Conventions and the Additional Protocol II. J. Toman, Cultural Property..., pp. 414-432; R. O'Keefe, The Protection of Cultural Property in Armed Conflict, pp. 97-98, 245-247.

49 Articles 10-14 of the Second Protocol.

50 In line with Article 18(3) of the Hague Convention and Article 3(2) of the Second Protocol.

51 ICRC Database on International Humanitarian Law Treaties, https://ihl-databases.icrc.org/applic/ ihl/ihl.nsf/States.xsp?xp_viewStates=XPages_NORMStatesParties\&xp_treatySelected $=400$ [accessed: 14.01.2018].

52 Ibidem.
} 
the UK will be bound, whether in international or non-international armed conflicts, by the rules of customary international law relevant to the protection of cultural property..$^{53}$

It is true that the application of the Act to conflicts such as those in Syria or Afghanistan may be limited. This is related chiefly to the fact that these conflicts take place in the territory of States which are non-Parties to either the Second Protocol or both the Hague Convention and its Protocols. This will not, however, be linked to the existence or the recognition of Daesh or the Taliban as States under international law, and certainly not because such organized groups are regarded as "occupying forces". They cannot be occupying forces because occupation arises only in situations of international armed conflict, where one State's armed forces place part or all of another State's territory under its authority, and where that authority is well established and can be exercised..$^{54}$ Arguably, the recognition of States does not lead to the attainment of legal personality in international law or the requirements for statehood under international law. ${ }^{55}$ Any such aspiring entities must, instead, satisfy in the first place the four key conditions set out in the 1933 Montevideo Convention on the Rights and Duties of States. ${ }^{56}$ Neither Daesh nor the Taliban would satisfy all the requirements for statehood at this point of time, and as they are not State Parties to the Hague Convention and its Protocols the application of the Act to them will be limited. ${ }^{57}$ Whilst the scope of application of the Act in this context is likely to be limited, this will not preclude the possibility of it being applied ratione personae to organized armed groups such as Daesh or the Taliban. The next section will explore the scope of the personal application of the Act.

\section{b) Do the Hague Convention and its Protocols apply to a non-signatory Party?}

A rather different question is the issue of who is bound by the Hague Convention and its Protocols. First and foremost, State Parties are bound by these treaties. Insofar as the ratione personae application of the Hague Convention is concerned,

53 J.-M. Henckaerts, L. Doswald-Beck, Customary International Humanitarian Law, Vols. I and II, Cambridge University Press, Cambridge 2006 (in the hard copy) and an updated online version at: https://ihl-databases.icrc.org/customary-ihl/eng/docs/v1_rul [accessed:14.01.2018] ("ClHL Study").

54 Article 42 of Convention No. IV Respecting the Laws and Customs of War on Land and its Annex: Regulations Concerning the Laws and Customs of War on Land, The Hague, 18 October 1907, 36 Stat 2277 TS 539, as well as Article 42 of Convention No. Il with Respect to the Laws and Customs of War on Land and its Annex: Regulations Concerning the Laws and Customs of War on Land, The Hague, 29 July 1899, 32 Stat 1803 TS 403 ("Hague Regulations") as reprinted in: D. Schindler, J. Toman (eds.), op. cit., pp. 55-87. For more analysis of the occupation see also Legal Consequences of the Construction of a Wall in the Occupied Palestinian Territory, Advisory Opinion of 9 July 2004, ICJ Reports, 2004, para. 78; Case Concerning Armed Activities on the Territory of the Congo (Democratic Republic of the Congo v. Uganda), Judgment of 19 December 2005, ICJ Reports, 2005, para. 172.

55 Montevideo Convention on the Rights and Duties of States, 26 December 1933, 49 Stat 3097, art. 3.

56 Ibidem, art. 1.

57 N. Zamir, The Armed Conflict(s) Against the Islamic State, "Yearbook of International Humanitarian Law" 2015, Vol. 18, pp. 91-121. 


\section{COMMENTARIES}

Agnieszka Jachec-Neale

there is no doubt that it applies to States which are Parties to the Convention and which have mutual relations. ${ }^{58}$ An application of the modified clausula si omnes means that the Act will bind the UK in any declared war or international armed conflict where its opponent/s or the other Parties to the conflict are also Parties to the Hague Convention, in their mutual relations. ${ }^{59}$

The UK will also be bound by the Hague Convention vis-à-vis an adversary who is not a Party to the Convention, but who has accepted it and is de facto complying with its provisions. ${ }^{60}$ This regulation will also extend to coalition operations. In situations where one of the coalition members is not a Party to the Hague Convention, the Convention and thus the Bill will not apply to the mutual relations between the UK and that coalition partner, ${ }^{61}$ unless such a Party makes a declaration and acts according to the relevant provisions. ${ }^{62}$

A separate question is whether the Act will apply to non-State Parties to the Hague Convention, such as organized armed groups in non-international armed conflicts. ${ }^{63}$ During the debate in the House of Commons, MPs questioned whether the Bill would apply because of the limitations of the Hague Convention and its Protocols in this respect. ${ }^{64}$ In this context, one has to stress that Article 19 of the 1954 Hague Convention has been viewed through a prism of the applicability of Article 3, common to the Geneva Conventions. In this context, UNESCO interpreted Article 19 as conferring a legal obligation on each adversary based on their "contractual engagements undertaken by a community of which he is a part". ${ }^{65}$ In other words, as the adopted international obligations became part of national law, they also become binding on "national citizens", including rebel forces. ${ }^{66} \mathrm{It}$ was

\footnotetext{
58 Article 18 of the Hague Convention; Article 18(3), Schedule 1 of the Cultural Property (Armed Conflicts) Act 2017, Chapter 6, 23 February 2017.

59 Ibidem. The existence of this principle can be traced back to the Hague Regulations. J. Toman, The Protection..., p. 198; idem, Cultural Property..., p. 65.

60 Article 18 of the Hague Convention; Article 18, Schedule 1 of the Cultural Property (Armed Conflicts) Act 2017; J. Toman, The Protection..., pp. 199-201.
}

61 C. Forrest, op. cit., p. 82.

62 Note that it remains unclear whether the UK issued such a declaration, in addition to the required actual compliance, in the context of the past involvement of the UK in coalition operations in Iraq from 2003 onwards.

63 The term "party" in this sentence denotes, in line with the commentary, any party to the conflict as opposed to the term Party/Parties, with an upper-case "P" to indicate a contracting State Party to the conflict, thus bound by the convention. J. Toman, Cultural Property..., pp. 409-410. One has to note, though, that whilst this is not exactly how the term "party" is included in Article 3 common to the Geneva Conventions, but is based on the interpretation and meaning espoused in the commentary, it appears to lead to the same result.

64 See text above attached to notes 39-41.

65 Toman relied here on the commentary to the 1949 Geneva Conventions. J. Toman, The Protection..., pp. 209, 211-212.

66 The only way to avoid the need for compliance with the legally binding obligations resulting from the Geneva Conventions was through the use of the denunciation procedure provided by the Conventions. 
only natural that authorities such as rebel forces would also be inclined, Toman argued, to protect cultural property in support of the nation or community for which they were fighting, and that destruction of it would contradict the aims of their struggle. ${ }^{67}$ However, it should not be surprising that Daesh did not hold back from the extensive destruction of Palmyra and other cultural sites and artefacts in Syria and Iraq, for their preservation would not have advanced their political or religious goals. ${ }^{68}$ One can also argue that the destruction of this cultural property might have been regarded as a show of strength and power in support of Daesh's ideological and religious convictions.

Both UNESCO and Toman's commentaries link the application with the concept of nationality or, more precisely, to all people under the relevant State's jurisdiction. This is admittedly only one of several theories proposed in support of the binding nature of Article 3 on non-State organized armed groups. ${ }^{69}$ The 2016 ICRC Commentary to the 1949 Geneva Conventions mentions four other possible justifications in this context, but avoids giving a definitive answer beyond restating that non-State organized groups are bound by the provisions of Article $3 .{ }^{70}$ There is no reason why Article 19 of the Hague Convention should not be seen as applicable to non-State organized armed groups, especially as this provision also explicitly refers to all parties to the conflict, and not State Parties.

Interestingly, during the negotiation of the 1954 Hague Conventions, the UK delegation was the only one to oppose the adoption of Article 19, considering it to be "unworkable". ${ }^{71}$ The delegation proposed deleting Article 19, or at least reformulating it, with the lesser obligation of "to endeavour" replacing "to be bound" to apply the provisions of the Convention by all parties to the conflict. The Committee of the Conference uniformly rejected this proposal and agreed to adopt Article $19 .{ }^{72}$

\footnotetext{
Note that this procedure would not, in most circumstances, be available to rebel forces or organized armed groups, as denunciation could be undertaken only by the authority internationally recognized as a competent government. Ibidem.

67 Ibidem.

68 P. Gerstenblith, The Destruction of Cultural Heritage: A Crime Against Property or a Crime Against People?, "John Marshall Review of Intellectual Property Law" 2016, Vol. 15(336), pp. 357-361.

69 For more on this, see L. Moir, The Law of the Internal Armed Conflict, Cambridge University Press, Cambridge 2002, pp. 52-58 and 96-99; L. Zegveld, The Accountability of Armed Opposition Groups in International Law, Cambridge University Press, Cambridge 2002, pp. 9-12; M. Sassòli, Taking Armed Groups Seriously: Ways to Improve Compliance with International Humanitarian Law, "Journal of International Humanitarian Legal Studies" 2010, Vol. 1(1), pp. 10-14; S. Sivakumaran, The Law of Non-International Armed Conflict, Oxford University Press, Oxford 2012, pp. 236-246.

70 Common Article 3 to 1949 Geneva Conventions, International Committee of the Red Cross, op. cit., paras. 504, 507-508.

71 UNESCO, Records..., para. 1065, also in J. Toman, The Protection..., pp. 209, 214.

72 J. Toman, The Protection..., pp. 209, 214.
} 


\section{COMMENTARIES}

Agnieszka Jachec-Neale

The word "endeavour" features, though, in Paragraph 2 of Article 19. It constitutes an invitation to all parties to the conflict to enter into bilateral agreements, permitting a wider scope of the protection of cultural property. Whilst allowing parties the freedom to extend the application of the Hague Convention, this opportunity has not been made use of in practice. Consequently, the experts in this field meeting in 1983 recognized that an effective realization of bilateral agreements during conflicts was unrealistic and unlikely to succeed. ${ }^{73}$ Accordingly, a suggestion was made that unilateral but concordant statements should be treated as a form of such "special agreements". ${ }^{4}$

Article 22 of the Second Protocol broadened the scope of its material application, as compared to the formula used in Article 19 of the Hague Convention. It also reinforced the remit of its personal application to all parties to the conflict, including non-State actors, in line with the application of the common Article 3 and the Additional Protocol II to the Geneva Convention. ${ }^{75}$

In light of the above, there could be two situations of non-international armed conflicts that may call for the application of the UK Cultural Property Act. The first would involve an armed conflict confined to the territory of the UK. The other would involve the UK as a party to a non-international armed conflict (NIAC) occurring on foreign territory. In both cases, the Act would be binding on the UK. There is no question that the Act itself would apply to UK personnel, both military and civilian, as well as UK nationals even in the context of armed conflicts occurring beyond the UK's borders. ${ }^{76}$ This may be an important issue, especially in NIACs fought on the territory of the State that has not ratified the Hague Convention or its Protocols.

In a NIAC occurring on UK territory, the Act will also be binding on any nonState actors engaged in a fight against the UK authorities, or in a struggle among themselves. In the second scenario, i.e. outside the UK's territory, foreign nonState actors may find themselves subject to the Act's regulation. Section 3 of the Act prescribes individual criminal responsibility for a serious violation of the Second Protocol, which can be committed by any person, regardless of their nationality, and anywhere in the world. ${ }^{77}$ Two prohibited acts include violations against

\footnotetext{
73 Ibidem, p. 216.

74 Ibidem.

75 Idem, Cultural Property..., p. 418.
}

76 Sections 3-4 of the Cultural Property (Armed Conflicts) Act 2017. As Sections 3 and 4 explicitly use the broad term, "persons", it is clear that this criminal jurisdiction could extend to residents or persons with other significant links to the UK, as prescribed in other UK domestic acts such as the International Criminal Court Act 2001 (Sections 51, 58, 68).

77 Section 4 enshrines the same regulation in regard to ancillary crimes. Sections 3-4 of the Cultural Property (Armed Conflicts) Act 2017. 
cultural property under enhanced protection, whilst a third refers to the extensive destruction of, or appropriation of, cultural property protected both under the Hague Convention and the Second Protocol. ${ }^{78}$

Additionally, non-State organized armed groups will be bound by the equivalent rules of customary international humanitarian law applicable in NIACs, and directly by the application of Article 19 if the conflict in question takes part on the territory of a State which is a Party to the Hague Convention. If the latter is also a Party to the Second Protocol, the non-State organized group will also be bound by the provisions of the Second Protocol, whose material application will, as mentioned above, go beyond the obligations to respect cultural property. ${ }^{79}$ In a situation where such a conflict occurs on the territory of a State which is not a Party to the Hague Convention and its Protocols, the non-State organized group will remain bound by the relevant customary international humanitarian law. It may, of course, be subject to criminal prosecution in relation to violations of the Hague Convention and the Second Protocol, as provided for by Sections 3 and 4 of the Act. ${ }^{80}$

In conclusion, and in response to the queries raised during the discussions in the House of Commons, one should be assured that organizations such as Daesh or Boko Haram, whilst not bound by the Act itself (except for the sections establishing individual criminal responsibility), will be bound by the provisions of the Hague Convention - or, at the very least, the relevant customary norms. ${ }^{81}$ This is because Iraq and the Syrian Arab Republic both ratified the Hague Convention. ${ }^{82}$ Nigeria is also Party to the 1999 Second Protocol so, in the context of the ongoing NIAC, the Boko Haram group will also be bound by the provisions of the Second Protocol. ${ }^{83}$ It is true that Afghanistan is not Party to any of these treaties, but the Taliban group will be bound by the relevant customary international humanitarian rules and, from September 2017, subject to possible criminal prosecution in line with the newly adopted Act's jurisdiction over criminal offences.

\footnotetext{
78 This represents the incorporation of Articles 15 and 16 of the Second Protocol into the Act. See also the further discussion in regard to criminal responsibility clauses in part three of this article.

79 See text attached to notes 49-51 above.

80 For a further discussion of the relevant customary international humanitarian law applicable to cultural property, see Rules 38-40 with its associated practice, as identified in a CIHL Study. See also P. Gerstenblith, op. cit., p. 352.

81 One should also bear in mind that the Act cannot be applied retrospectively.

82 ICRC Database on International Humanitarian Law Treaties, op. cit.

83 Ibidem. Some provisions of the Hague Convention and its Protocols, and consequently of the Act, apply both during peacetime and during armed conflicts. For the latter provisions to come into play, an armed conflict needs to involve the UK as one of the parties. The UK does not appear to be currently involved in armed conflict against Boko Haram.
} 


\section{COMMENTARIES}

Agnieszka Jachec-Neale

\section{Definition of Cultural Property}

The definition of cultural property incorporated into the Cultural Property Act follows to the letter the definition adopted in the Hague Convention. ${ }^{84}$ Article 1 of the latter prescribes that cultural property is property, both movable and immovable, of great importance to the cultural heritage of every people. ${ }^{85}$ This provided for a more general definition, which was preferred by some of the negotiating delegates in 1954 in The Hague. ${ }^{86}$ It has been supplemented by a non-exhaustive list of examples, including monuments of art, architecture, or history, archaeological sites, assemblages of buildings of historical or artistic interest, as well as works of art, scientific collections, book collections and archives, and - importantly - collections of reproductions of cultural property. ${ }^{87}$ The definition of cultural property also includes buildings dedicated to preserving or exhibiting movable cultural property, such as museums, libraries, depositories of archives and - during an armed conflict - storage and shelter facilities, and centres containing monuments. ${ }^{88}$ This definition is considered to reflect customary international law. ${ }^{89}$

The definition was adopted with the aim of arriving at a common standard that would be acceptable to the majority of States. The ownership or origin of the property is irrelevant in this context; what is important is its value to the cultural heritage of a people. This value is based on the property's importance, which implies a subjective and relative element. Such value is inherently difficult to determine using uniform and conclusive criteria.

As noted by one peer during the second reading of the Bill in the House of Lords, the perception of what constitutes cultural property or cultural heritage changes over time..$^{90}$ In this day and age, some works of art exist only in digital form. Thus, concern was expressed during the debates in Parliament about whether the Act would also encompass digital cultural property. The Secretary of State for Culture, Media and Sport, Karen Bradley, gave an assurance that the definition was broad enough to include "modern or digital types of cultural prop-

\footnotetext{
84 Section 1 of the Cultural Property (Armed Conflicts) Act 2017.

85 Article 1 of the Hague Convention.

86 J. Toman, The Protection..., p. 48.

87 This definition is replicated by the subsequent Protocols. Article 1 of the Hague Convention; Article 1 of the First Protocol and Article 1 of the Second Protocol.

88 Ibidem.

89 UK Ministry of Defence, The Manual on the Law of Armed Conflict, Oxford University Press, Oxford 2004 ("UK Manual"), p. 71. Note that the description of cultural property subject to enhanced protection by the operation of the Second Protocol was deemed to be treaty-based only. M.N. Schmitt (ed.), Tallinn Manual 2.0 on the International Law Applicable to Cyber Operations, 2nd edn., Cambridge University Press, Cambridge 2017 (“Tallinn Manual 2.0"), p. 534.
}

90 Statement of the Earl of Clancarty, Cultural Property (Armed Conflicts) Bill, HL Deb 6 June 2016 vol. 773 col. 598 . 
erty". ${ }^{91}$ It is, after all, up to the UK to designate which property within its territory is of great importance to its cultural heritage. One may ask whether the concern of the Peers, and subsequently the Members of Parliament, was justified? Yes, certainly. Recent debates surrounding the law of cyber operations show that there could be a real risk to the full inclusion of digital cultural property as being subject to protection during armed conflicts in cyber space.

The International Group of Experts working on the 2013 Tallinn Manual on Cyber Warfare, and its updated version in 2017, was seemingly split in determining whether non-tangible manifestations of cultural property were subject to protection against the effects of cyber operations. ${ }^{92}$ Some experts relied on a literal reading of Article 53 of Additional Protocol I, which offers protection to "cultural objects" and places of worship. ${ }^{93}$ This definition is wider than the Hague Convention in that it covers places of worship and cultural objects, which constitute the spiritual heritage of peoples. However, the protection offered in Article 53 is not conferred on, for example, museums, libraries, or centres of monuments. It differs from the scope identified in Rule 38 of the CIHL Study, which follows the wider definition of cultural property in the Hague Convention, which is considered the customary norm. The general interpretation, though, is that both regulations do relate to physical, tangible items. ${ }^{94}$

Accordingly, the experts argued that the term "objects" pertained only to tangible physical objects, and thus limited the notion of cultural property to tangible objects - with the exclusion of any intangible pieces, such as digital cultural property. ${ }^{95}$ Other experts noted that in other branches of law, the notion of property also encompassed intangible items such as intellectual property. For them, the relevant question was whether such property could meet a cultural requirement. ${ }^{96}$ It appears that the experts working on the Tallinn Manual could not come to an agreement on this issue, either in 2013 or 2017 . Whilst they recognized that cultural property needs to be protected, they left open the question of the status of digital cultural property.

Given that the Hague Convention and its Protocols offer much more specific, detailed, and well established regulation than the current understanding of what

\footnotetext{
91 Statement of Karen Bradley, the Secretary of State for Culture, Media and Sport, Cultural Property (Armed Conflicts) Bill, HC Deb 31 October 2016 vol. 616 col. 698.

92 Tallinn Manual 2.0, p. 535.

93 Article 53 of the Additional Protocol I provides that it is prohibited: "(a) to commit any acts of hostility directed against the historic monuments, works of art or places of worship which constitute the cultural or spiritual heritage of peoples".

94 C. Johannot-Gradis, Protecting the Past for the Future: How Does Law Protect Tangible and Intangible Heritage in Armed Conflict?, "International Review of the Red Cross" 2015, Vol. 97, p. 1259.

95 Tallinn Manual 2.0, p. 535.

96 Ibidem.
} 


\section{COMMENTARIES}

Agnieszka Jachec-Neale

rules may govern the conduct of cyber operations, the former should be the guiding legislation in relation to digital cultural property. This is in accordance with the well-established rule of lex specialis derogat legi generali. This approach also has a potential to permit more consistent legal findings than those identified in the Tallinn Manual. The starting point has to be the Hague Convention's definition of cultural property, which does not, in principle, prohibit its application to non-material items. The concept of property implies an idea of ownership, rather than being dependent on the nature of the asset. As it is up to each individual State to designate a list of its cultural property, it may include digital cultural assets. It is possible that a digital recording of an anthem or a digital reproduction of a famous painting may constitute cultural property within the definition of the Act. In other words, there is nothing in the Hague Convention, and consequently in the Act, to prevent such property being so determined, either by the UK or by any other States Parties. However, given the historic interpretation of the Hague Convention's definition of cultural property, it remains to be seen whether cultural property will indeed encompass digital forms of representation. ${ }^{97}$

\section{Conclusions}

There is no doubt that ratification of the Hague Convention and its Protocols by the UK came as a much awaited and welcome step. It enables the UK authorities to provide a much greater protection of cultural property located in the UK in the event of an armed conflict, and possibly opens the door to domestic prosecutions of serious breaches of the Second Protocol against non-nationals in the forum State. However, despite some attempts to tackle some of the challenging and topical issues, the new legislation does not resolve some of the contemporary debates. One may say that this was not the purpose of the process, but at the same time this was a missed opportunity to address some of the more thorny issues. Neither the new legislation nor the debates in Parliament provide much of an insight into whether, for example, non-tangible digital cultural property is also protected. When giving effect to the repression of violations in its domestic jurisdiction, in line with Article 28 of the Hague Convention, the UK decided to establish a broad jurisdictional basis that permits the criminal prosecution of offences committed by non-nationals outside the territory of the forum State, including - in the context of non-international armed conflicts - going beyond

97 This will be also relevant to a discussion about the status of digital archives and collections, digital reproductions of cultural property, and digital storage. In the specific context of digital reproductions of cultural property, there has been made an unwarranted conclusion that only some reproductions - either limited in amount, or related to original property which has been destroyed - should achieve the status of protected cultural property (Tallinn Manual 2.0, p. 535). This does not seem to be matched by an equivalent limitation on reproductions of cultural property under the Hague Convention. 
mere respect-related provisions. However, this issue remains contested, and other States may well take a different position in this regard..$^{98}$

For the UK, the ratification was in practice merely a formality. Its armed forces had already been observing their duties to protect cultural property during military operations, and had been trained accordingly since the UK became Party to Additional Protocol I to the Geneva Conventions in the late 1990s. Respect for cultural property was not only incorporated in the UK Manual of the Law of Armed Conflict, ${ }^{99}$ but also in the targeting doctrine and policy and in the military practice. ${ }^{100}$ The Act has formalized these responsibilities for UK personnel. ${ }^{101}$ In early 2014, a joint military cultural property protection working group began working on establishing a unit of specialists dedicated to the protection of cultural property, and reviewing training in this field. ${ }^{102}$ There is no doubt that the UK's engagement in the protection of cultural property, both domestically and worldwide, is a serious commitment, and the ratification of the relevant treaties represents yet another reflection of this. Time will tell whether this commitment will translate into the active prosecution of cases, which would add further clarity on the interpretational issues left unresolved in the debates during the ratification process.

\section{References}

Cabinet Office, Queen's Speech 2016, 18 May 2016, https://www.gov.uk/government/ speeches/queens-speech-2016 [accessed: 15.01.2018].

Cabinet Office, Queen's Speech 2016: Background Briefing Notes, 18 May 2016, https:// www.gov.uk/government/uploads/system/uploads/attachment_data/file/524040/ Queen_s_Speech_2016_background_notes_.pdf [accessed: 15.01.2018].

Case Concerning Armed Activities on the Territory of the Congo (Democratic Republic of the Congo v. Uganda), Judgment of 19 December 2005, IC J Reports, 2005.

Convention for the Protection of Cultural Property in the Event of Armed Conflict, 14 May 1954, 249 UNTS 240.

Convention for the Protection of Cultural Property in the Event of Armed Conflict with Regulations for Execution of the Convention 1954 - Opened for Signature, http://portal. unesco.org/en/ev.php-URL_ID=13637\&URL_DO=DO_TOPIC\&URL_SECTION=201. htmI\#SIGNATURE [accessed: 14.01.2018].

\footnotetext{
98 For more on these two differing approaches, see the discussion in R. O'Keefe, Protection of Cultural Property under International Criminal Law, "Melbourne Journal of International Law" 2010, Vol. 11, pp. 22-26.

99 UK Manual.

100 CMSC Draft Bill, pp. 8-10.

101 The Bill has failed to clarify whether it shall also apply to foreign personnel embedded in the UK's armed forces, J. Woodhouse, A. Lang, C. Mills, Cultural Property (Armed Conflicts) Bill [HL] (Bill 66 of 2016-17), Briefing Paper No. 7745, 25 October 2016, pp. 18-19.

102 T. Purbrick, Monuments Men: Part One, "British Army Blog", 21 October 2016, https://britisharmy. wordpress.com/2016/10/21/monuments-men-part-one/ [accessed: 27.01.2018]; idem, Monuments Men: Part Two, "British Army Blog", 29 November 2016, https://britisharmy.wordpress.com/2016/11/29/monuments-men-part-two/ [accessed: 27.01.2018].
} 


\section{COMMENTARIES}

Agnieszka Jachec-Neale

Convention No. II with Respect to the Laws and Customs of War on Land and its Annex: Regulations Concerning the Laws and Customs of War on Land, The Hague, 29 July 1899, 32 Stat 1803 TS 403.

Convention No. IV Respecting the Laws and Customs of War on Land and its Annex: Regulations Concerning the Laws and Customs of War on Land, The Hague, 18 October 1907, 36 Stat 2277 TS 539.

Council for British Archaeology, CBA Pushes for Definite Timescales for Protection of Cultural Property, 21 June 2015, http://new.archaeologyuk.org/news/cba-pushes-for-definite-timescales-for-protection-of-cultural-property [accessed: 27.01.2018].

Cultural Property (Armed Conflicts) Act 2017, Chapter 6, 23 February 2017.

Dealing in Cultural Objects (Offences) Act 2003, Chapter 27, 30 October 2003.

Department for Culture, Media and Sport, Consultation Paper on: The 1954 Hague Convention on the Protection of Cultural Property in the Event of Armed Conflict and its two Protocols of 1954 and 1999, September 2005, http://webarchive.nationalarchives.gov. uk/20100512164615/http://www.culture.gov.uk/images/consultations/HagueConvention.pdf [accessed: 20.09.2017].

Department for Culture, Media and Sport, Cultural Property (Armed Conflicts) Bill, Explanatory Notes, published together with Draft Bill, May 2016.

Department for Culture, Media and Sport, Draft Cultural Property (Armed Conflicts) Bill, January $2008, \mathrm{Cm} 7798$.

Department for Culture, Media and Sport, Government Response to the Culture, Media and Sport Committee Reports on the Draft Heritage Protection Bill and Draft Cultural Property (Armed Conflicts) Bill, October 2008, Cm 7472.

Department for Culture, Media and Sport, Hague Convention 1954, 12 February 2014, http:// old.culture.gov.uk/what_we_do/cultural_property/6630.aspx [accessed: 20.09.2017].

Department for Culture, Media and Sport, Ratification of 1954 Hague Convention for the Protection of Cultural Property in the Event of Armed Conflict and Accession to Its Two Protocols (of 1954 and 1999), Impact Assessment, 1 May 2016.

Forrest C., International Law and the Protection of Cultural Heritage, Routledge, London 2010.

Geneva Convention (I) for the Amelioration of the Condition of the Wounded and Sick in Armed Forces in the Field, 12 August 1949, 75 UNTS 31.

Geneva Conventions Act 1957, 1957 Chapter 525 and 6 Eliz 2, 31 July 1957, with subsequent amendments.

Gerstenblith P., The Destruction of Cultural Heritage:A Crime Against Property or a Crime Against People?, "John Marshall Review of Intellectual Property Law" 2016, Vol. 15(336).

Gill T.D., Classifying the Conflict in Syria, "International Law Studies" 2016, Vol. 92.

Hampson F., Afghanistan 2001 onwards, in: E. Wilmshurst (ed.), International Law and Classification of Armed Conflicts, Oxford University Press, Oxford 2012.

Henckaerts J.-M., Doswald-Beck L., Customary International Humanitarian Law, Vols. I and II, Cambridge University Press, Cambridge 2006.

House of Commons, Culture, Media and Sport Committee, Draft Cultural Property (Armed Conflicts) Bill, 15 July 2008, HC 693.

International Committee of the Red Cross, Commentary on the First Geneva Convention: Convention (I) for the Amelioration of the Condition of the Wounded and Sick in Armed Forces in 
the Field, 2nd edn., Cambridge University Press, Cambridge 2016, https://ihl-databases.icrc.org/ihl/full/GCl-commentary [accessed: 14.01.2018].

Johannot-Gradis C., Protecting the Past for the Future: How Does Law Protect Tangible and Intangible Heritage in Armed Conflict?, "International Review of the Red Cross" 2015, Vol. 97.

Legal Consequences of the Construction of a Wall in the Occupied Palestinian Territory, Advisory Opinion of 9 July 2004, ICJ Reports, 2004.

Moir L., The Law of the Internal Armed Conflict, Cambridge University Press, Cambridge 2002.

Montevideo Convention on the Rights and Duties of States, 26 December 1933, 49 Stat 3097.

O'Keefe R., Protection of Cultural Property under International Criminal Law, "Melbourne Journal of International Law" 2010, Vol. 11.

O'Keefe R., The Protection of Cultural Property in Armed Conflict, Cambridge University Press, Cambridge 2006.

Protection of Cultural Property (Convention), HC Deb (19 November 1958) vol. 595 col. 1142.

Protocol Additional to the Geneva Conventions of 12 August 1949, and Relating to the Protection of Victims of International Armed Conflict (Protocol I), 8 June 1977, 1125 UNTS 3.

Protocol Additional to the Geneva Conventions of 12 August 1949, and Relating to the Protection of Victims of Non-International Armed Conflicts (Protocol II), 8 June 1977, 1125 UNTS 609.

Protocol for the Protection of Cultural Property in the Event of Armed Conflict, 14 May 1954, 249 UNTS 358.

Purbrick T., Monuments Men: Part One, "British Army Blog", 21 October 2016, https:// britisharmy.wordpress.com/2016/10/21/monuments-men-part-one/ [accessed: 27.01.2018].

Purbrick T., Monuments Men: Part Two, "British Army Blog", 29 November 2016, https:// britisharmy.wordpress.com/2016/11/29/monuments-men-part-two/ [accessed: 27.01.2018].

Sassòli M., Taking Armed Groups Seriously: Ways to Improve Compliance with International Humanitarian Law, "Journal of International Humanitarian Legal Studies" 2010, Vol. 1(1).

Schindler D., Toman J. (eds.), The Laws of Armed Conflicts, 4th edn., Martinus Nijhoff, Leiden 2004.

Second Protocol to the Hague Convention for the Protection of Cultural Property in the Event of Armed Conflict, 26 March 1999, 2253 UNTS 212.

Sivakumaran S., The Law of Non-International Armed Conflict, Oxford University Press, Oxford 2012.

Schmitt M., Iraq 2003 Onwards, in: E. Wilmshurst (ed.), International Law and Classification of Armed Conflicts, Oxford University Press, Oxford 2012.

Schmitt M.N. (ed.), Tallinn Manual 2.0 on the International Law Applicable to Cyber Operations, 2nd edn., Cambridge University Press, Cambridge 2017. 


\section{COMMENTARIES}

Agnieszka Jachec-Neale

Statement of Baroness Neville-Rolfe, Parliamentary Under-Secretary of State, Department for Business, Innovation and Skills and Department for Culture, Media and Sport, HL Deb 14 January 2016 vol. 768 cols. 501-502.

Statement of Edward Vaizey, Minister of State for Culture and the Digital Economy, HC Deb 4 June 2015 vol. 596 col. 739.

Statement of Karen Bradley, the Secretary of State for Culture, Media and Sport, Cultural Property (Armed Conflicts) Bill, HC Deb 31 October 2016 vol. 616 col. 698.

Statement of Kevin Brennan, MP, Cultural Property (Armed Conflicts) Bill, HC Deb 31 October 2016 vol. 616 col. 704.

Statement of the Earl of Clancarty, Cultural Property (Armed Conflicts) Bill, HL Deb 6 June 2016 vol. 773 col. 598.

Statement of Tim Loughton, MP, Cultural Property (Armed Conflicts) Bill, HC Deb 31 October 2016 vol. $616 \mathrm{col} .734$.

Statement of Tracey Crouch, Parliamentary Under-Secretary of State for Culture, Media and Sport, Cultural Property (Armed Conflicts) Bill, HC Deb 31 October 2016 vol. 616 col. 738.

Toman J., Cultural Property in War: Improvement in Protection: Commentary on the 1999 Second Protocol to the Hague Convention of 1954 for the Protection of Cultural Property in the Event of Armed Conflict, UNESCO, Paris 2009.

Toman J., The Protection of Cultural Property in the Event of Armed Conflict: Commentary on the Convention for the Protection of Cultural Property in the Event of Armed Conflict and Its Protocol, Signed on 14 May 1954 in the Hague, and on Other Instruments of International Law Concerning Such Protection, Aldershot, Dartmouth 1996.

UK Ministry of Defence, The Manual on the Law of Armed Conflict, Oxford University Press, Oxford 2004.

UK Parliament, Bill Stages - Cultural Property (Armed Conflicts) Act 2017, https://services. parliament.uk/bills/2016-17/culturalpropertyarmedconflicts/stages.html [accessed: 28.09.2017].

UNESCO, Records of the Conference Convened by the United Nations Educational, Scientific, and Cultural Organization, Held at The Hague from 21 April to 14 May 1954, Staatsdrukkerijen Uitgeverijbedrijf, The Hague 1961.

Woodhouse J., Lang A., Mills C., Cultural Property (Armed Conflicts) Bill [HL] (Bill 66 of 2016-17), Briefing Paper No. 7745, 25 October 2016.

Zamir N., The Armed Conflict(s) Against the Islamic State, "Yearbook of International Humanitarian Law" 2015, Vol. 18.

Zegveld L., The Accountability of Armed Opposition Groups in International Law, Cambridge University Press, Cambridge 2002. 